\title{
Effect of replacing wheat bran with spineless cactus plus urea in sugarcane-based diets for sheep
}

\author{
S.E.B. Lins ${ }^{1}$, R.A. Pessoa ${ }^{2}$, M.A. Ferreira ${ }^{2}$, J.M.S. Campos ${ }^{1}$, J.A.B.A. Silva ${ }^{1}$, S.A. Santos ${ }^{3}$, J.L. \\ Silva" ${ }^{4 \#}$, T.T.B. Melo ${ }^{2} \&$ J.C.C. Chagas ${ }^{1}$ \\ ${ }^{1}$ Academic Unit of Garanhuns, Federal Rural University of Pernambuco, Bom Pastor Avenue, s/n, Boa Vista, Garanhuns, \\ PE, Brazil, Zip Code: 55292-270 \\ ${ }^{2}$ Department of Animal Science, Federal Rural University of Pernambuco, Dom Manoel de Medeiros Street, $s / n$, Dois \\ Irmãos, Recife, PE, Brazil, Zip Code: 52171-900 \\ ${ }^{3}$ Department of Animal Science, Federal University of Bahia, Adhemar de Barros Avenue, Ondina, Salvador, BA, Brazil, \\ Zip Code: 40170-110 \\ ${ }^{4}$ Multidisciplinary Center of Barra, Federal University of West of Bahia, Barra, BA, Brazil, Zip Code: 47100-000
}

(Received 28 July 2015; Accepted 1 June 2017; First published online 12 June 2017)

Copyright resides with the authors in terms of the Creative Commons Attribution 4.0 South African License.
See: http://creativecommons.org/licenses/by/4.0/za
Condition of use: The user may copy, distribute, transmit and adapt the work, but must recognize the authors and the South African
Journal of Animal Science.

\begin{abstract}
In times of drought, the availability of feed is reduced, and the use of concentrate ingredients, such as wheat bran, becomes costly for animal production. Thus, the use of spineless cactus emerges as a potential solution to the shortage of feed and water during prolonged drought periods. The objective of this study was to evaluate the effects of replacing wheat bran with spineless cactus plus urea $(0 \%, 25 \%, 50 \%, 75 \%$, and $100 \%$ in sugarcane-based diets for sheep on nutrient intake, feeding behaviour, nitrogen balance and microbial protein synthesis. Five male Santa Ines sheep with average initial bodyweight of $34.0 \pm 3.6 \mathrm{~kg}$ were used in a $5 \times 5$ Latin square. The maximum intakes of dry matter (DM) (1414 g/day), organic matter (OM) (1281 g/day), crude protein (CP) (204 g/day), neutral detergent fibre corrected for ash and protein (NDFap) (425 g/day), and total digestible nutrients (TDN) $(890 \mathrm{~g} /$ day) were estimated with replacement levels of $80.2 \%, 75.3 \%, 88.6 \%, 50.5 \%$, and $79.3 \%$ respectively. Feeding behaviour was not altered by replacing wheat bran with spineless cactus plus urea. Nitrogen retention increased by $0.10 \mathrm{~g} / \mathrm{day}$, while plasmatic urea nitrogen increased by $0.20 \mathrm{mg} /$ day for every $1 \%$ level of replacement. The maximum production of microbial nitrogen (15.9 g/day) and microbial protein synthesis $(99.4 \mathrm{~g} /$ day) were estimated with replacement levels of 45.8 and $45.7 \%$, respectively. It is concluded that up to $80 \%$ wheat bran could be replaced with spineless cactus plus urea in sugarcane-based diets for sheep.
\end{abstract}

Keywords: Alternative feed, drought, feeding behaviour, intake, microbial protein

\#Corresponding author: silva janainalima@yahoo.com.br; janainal.lima@ufob.edu.br

\section{Introduction}

Animal production systems in tropical regions, particularly those in semi-arid regions, are informal and depend on native vegetation. In times of drought, the availability of feed is reduced and the use of concentrate ingredients such as wheat bran becomes costly for animal production. Therefore, it is necessary to further the development of techniques that increase the production efficiency of herds.

Ensuring the availability of alternative feeds in adequate amounts and of adequate quality is a priority to keep up with accelerated demand for growing and finishing animals, since droughts and changes in global climate affect the grain harvest and increase prices in the international market (Ben Salem \& Smith, 2008).

Spineless cactus, because of its efficiency of water use (Nobel, 2001), emerges as a potential solution to the shortage of feed and water during prolonged drought. It is utilized as a feed supplement in Brazil, Chile, Morocco, Mexico, South Africa and Tunisia (Ben Salem \& Smith, 2008). In Brazilian semi-arid regions, it is common to use the spineless genotypes giant (Opuntia ficus-indica meal), sweet (Nopalea cochenillifera (L.) Salm-Dyck), and Mexican elephant ear (Opuntia stricta (Haw.)).

The main advantage of spineless cactus is the presence of high concentration of water in the cladodes 
(850-900 g/kg) (Nefzaoui \& Ben Salem, 2002), which contributes to the hydration of animals. Moreover, it is rich in rapid rumen fermentation carbohydrates (640-710 $\mathrm{g} / \mathrm{kg}$ of dry matter (DM)) (Nefzaoui \& Ben Salem, 2002) and has higher DM digestibility $(750 \mathrm{~g} / \mathrm{kg}$ ) (Ferreira et al., 2011). Its neutral detergent fibre content (NDF) 170-280 g/kg DM), and CP content (25-60 g/kg DM) (Nefzaoui \& Ben Salem, 2002), however, are relatively low, which suggests the presence of an association between roughage with effective fibre and the supply of rumen degradable protein to optimize microbial protein synthesis (NRC, 2001).

When the aim is to potentiate rumen microbial protein synthesis with the use of urea, evaluation of the nitrogen balance is an important tool, because it can help to determine the efficiency of the use of nitrogen by ruminants and its losses in the environment. According to Bastos et al. (2014), feeding conditions and characteristics of feed can alter feeding behaviour owing to interactions among the nutrients of diets and increase microbial efficiency.

In the literature, few studies evaluate the replacement of wheat bran with spineless cactus in the diets of sheep. In heifers, Monteiro et al. (2014) reported that it was practical to replace wheat bran with spineless cactus containing urea up to $66 \%$ DM in sugar cane-based diets. This could contribute to reducing the costs of concentrate feeds. It is hypothesized that spineless cactus, which is high in non-fibre carbohydrates, could replace wheat bran in supplementation strategies in sheep production systems. Del Razo et al. (2015) suggest that cladodes of spineless cactus could be fed to ruminants in the place of lucerne and oat hays without compromising the performance of the animals. The focus should now be on the formulation of spineless cactus production diets with a high energy content to be used in feedlots. Supplementing additional protein and energy feed sources would probably improve animal performance (Einkamerer et al., 2009).

Therefore, the purpose of this study was to evaluate the effects of replacing wheat bran with spineless cactus plus urea in sugarcane-based diets for sheep on nutrient intake, feeding behaviour, nitrogen balance, and microbial protein synthesis.

\section{Materials and Methods}

The experiment was conducted at the Laboratory of Feed Evaluation for Small Ruminants II in the Department of Animal Science of the Federal Rural University of Pernambuco, Recife, PE, Brazil.

The ingredients used in the diets were sugarcane (Saccharum officinarum L.), ground corn, wheat bran, and spineless cactus (Nopalea cochenillifera Salm-Dyck) (Table 1). The sugarcane was chopped to particles about $1 \mathrm{~cm}$. Dietary treatments consisted of a control diet with wheat bran and without spineless cactus, and four diets with spineless cactus replacing $25 \%, 50 \%, 75 \%$, and $100 \%$ wheat bran, respectively (Table 2). Spineless cactus was chopped daily and thoroughly mixed with the other ingredients prior to feeding. Urea and ammonium sulfate were added to the diets to adjust the CP of the spineless cactus. Diets were offered as total mixed rations twice daily in two equal meals at 8h00 and $16 \mathrm{~h} 00$ for ad libitum intake, and the amounts fed and refused were recorded daily, maintained at about $13 \%$ orts. The orts were sampled, placed in labelled bags, and stored in the freezer for later analysis.

Table 1 Chemical composition of sugarcane, corn, wheat bran and spineless cactus used in the experimental diets (on a dry matter basis, $\mathrm{g} / \mathrm{kg}$ )

\begin{tabular}{lcccc}
\hline \multirow{2}{*}{ Item } & \multicolumn{3}{c}{ Ingredients } \\
\cline { 2 - 5 } & Sugarcane & Corn & $\begin{array}{c}\text { Wheat } \\
\text { bran }\end{array}$ & Spineless cactus \\
\hline Dry matter & 275 & 888 & 908 & 99.1 \\
Organic matter & 968 & 983 & 891 & 851 \\
Crude protein & 24.0 & 88.7 & 159 & 51.0 \\
Ether extract & 9.10 & 46.0 & 50.3 & 13.5 \\
Neutral detergent fibre ap ${ }^{1}$ & 440 & 190 & 434 & 232 \\
Non-fibre carbohydrates & 495 & 658 & 247 & 555 \\
\hline
\end{tabular}

${ }^{1}$ Corrected for ash and protein 
The management and care of animals were performed in accordance with the guidelines and recommendations of the Committee of Ethics on Animal Studies at the Federal Rural University of Pernambuco (UFRPE), PE, Brazil. Five non-castrated male Santa Ines sheep (34.0 $\pm 3.6 \mathrm{~kg}$ bodyweight), cannulated in the rumen, were used in a $5 \times 5$ Latin square experiment. Each period lasted 15 days, with the first eight days for diet adaptation (Storry \& Sutton, 1969; Menezes et al., 2011), followed by seven days for data collection. Sheep were housed in individual pens with wooden floors and had free access to water.

Table 2 Proportion of ingredients and chemical composition of the diets with spineless cactus replacing $0 \%$, $25 \%, 50 \%, 75 \%$, and $100 \%$ wheat bran

\begin{tabular}{|c|c|c|c|c|c|}
\hline & \multicolumn{5}{|c|}{ Replacement levels (\% DM) } \\
\hline & 0 & 25 & 50 & 75 & 100 \\
\hline \multicolumn{6}{|l|}{ Ingredients (g/kg) } \\
\hline Sugarcane & 369 & 369 & 373 & 375 & 377 \\
\hline Corn & 79.3 & 79.9 & 80.6 & 80.8 & 80.8 \\
\hline Wheat bran & 529 & 396 & 262 & 127 & 0 \\
\hline Spineless cactus & 0 & 125 & 249 & 375 & 492 \\
\hline Urea/AS ${ }^{1}$ & 13.4 & 19.3 & 26.3 & 32.4 & 39.4 \\
\hline Mineral & 7.28 & 7.33 & 7.38 & 7.41 & 7.40 \\
\hline Sodium chloride & 2.36 & 2.41 & 2.46 & 2.46 & 2.49 \\
\hline \multicolumn{6}{|c|}{ Chemical composition ( $\mathrm{g} / \mathrm{kg}$ on DM basis) } \\
\hline Dry matter & 490 & 314 & 232 & 184 & 154 \\
\hline Organic matter & 943 & 932 & 923 & 913 & 903 \\
\hline Crude protein & 136 & 137 & 140 & 141 & 146 \\
\hline Ether extract & 30.4 & 26.3 & 22.1 & 17.8 & 13.8 \\
\hline NDFap ${ }^{2}$ & 407 & 379 & 351 & 323 & 296 \\
\hline $\mathrm{iNDF}^{3}$ & 160 & 189 & 201 & 199 & 180 \\
\hline Non-fibre carbohydrates & 392 & 422 & 453 & 484 & 513 \\
\hline
\end{tabular}

The faecal DM output was estimated using the total collection of faeces, which was performed from the first to the third day of each collection period. The collection bags were coupled to animals, and the samples were collected over 24 hours and kept frozen.

At the end of each experimental period, the feed samples, orts and faeces were thawed and subjected to pre-drying at $60{ }^{\circ} \mathrm{C}$ for 72 hours, and were then ground in a Wiley-type knife mill with a $1 \mathrm{~mm}$ mesh. Composite samples were saved for each animal on a dry weight basis from each period. Four hours after the diet was consumed on the 11th day of each experimental period, blood was collected by jugular vein puncture in a test tube containing a separation gel with a coagulant activator (SST II Advance, BD Vacutainer, Brazil). These samples were stored at $-15{ }^{\circ} \mathrm{C}$ for later urea analyses. Plasmatic urea nitrogen (PUN) was analysed with a commercial kit, Doles ${ }^{\circledR}$, and a colorimetric method in the semi-automatic biochemical analyzer D-250 Doles ${ }^{\circledR}$.

Feeding behaviour of all sheep was observed every 5 minutes for 24 hours, starting immediately after the morning feeding, totalling 72 hours of observation (three days of observation in each period). The activity of each sheep was recorded as feeding, ruminating, and resting. Each observation was assumed to last 5 minutes, which was the interval between observations. A meal was defined as at least one observation of feeding activity occurring after at least 20 minutes without feeding activity. This is based on the definition of feeding used by Wangsness et al. (1976), who defined a meal as at least one minute of eating activity after at least 20 minutes without eating. A period of rumination was defined as at least 5 minutes of rumination occurring after at least 5 minutes without ruminating activity. The feeding and rumination efficiencies $(\mathrm{g} / \mathrm{h})$ of 
DM and NDF were determined and adapted the methodology proposed by Bürger et al. (2000), dividing the intake of each of these nutrients by the total feeding time (feed efficiency) and rumination time (rumination efficiency).

The DM, OM, and CP analyses were performed according to the AOAC (1990) (method number 934.01 for DM, 930.05 for OM, and 981.10 for $\mathrm{CP}$ ). Ether extract (EE) was analyzed by Soxhlet extraction with petroleum ether, according to the AOAC (1990), method number 920.39. The concentration of neutral detergent fibre was assayed with a heat-stable amylase and corrected for ash and nitrogenous compounds (NDFap) by using techniques described by Mertens (2002), with corrections for a protein according to Licitra et al. (1996) and thermostable alpha-amylase added. Non-fibre carbohydrates (NFC) were calculated according to Hall (2000):

$\mathrm{NFC}(\mathrm{g} / \mathrm{kg})=1000-[(\mathrm{CP}$-urea derived CP + urea $)+\mathrm{NDFap}+\mathrm{EE}+\mathrm{ash}]$

Where: $\mathrm{CP}=$ crude protein

NDFap $=$ neutral detergent fibre corrected for ash and protein

$\mathrm{EE}=$ ether extract.

The total digestible nutrients (TDN) were determined according to Weiss (1999):

$\mathrm{TDN}=\mathrm{CP}_{\mathrm{d}}+\mathrm{NFC}_{\mathrm{d}}+\mathrm{NDF}_{\mathrm{d}}+\mathrm{EE}_{\mathrm{d}} \times 2.25$ (subscript means digestible).

$\mathrm{N}$ retention ( $\mathrm{N}$ balance, $\mathrm{g} / \mathrm{day}$ ) was calculated by the formula:

$N R=N_{\text {ing }}-N_{\text {urinary }}-N_{\text {fecal }}$,

Where: $\mathrm{NR}=$ nitrogen retention $(\mathrm{g})$

$\mathrm{N}_{\text {ing }}=$ nitrogen ingested $(\mathrm{g})$

$\mathrm{N}_{\text {urinary }}=$ nitrogen excreted in the urine $(\mathrm{g})$

$\mathrm{N}_{\text {fecal }}=$ nitrogen excreted in the faeces $(\mathrm{g})$

$\mathrm{N}$ absorbed $=\mathrm{N}_{\text {ingested }}-\mathrm{N}_{\text {fecal }}$.

The amount of absorbed microbial purines ( $\mathrm{X}, \mathrm{mmol} / \mathrm{day})$ was estimated based on the urinary excretion of purine derivatives ( $\mathrm{Y}, \mathrm{mmol} / \mathrm{day})$, by using the equation proposed by Chen \& Gomes (1992) for sheep:

$$
\mathrm{Y}=0.84 X+\left(0.150 \mathrm{BW}^{0.75} \mathrm{e}^{-0.25 X}\right),
$$

Where: $\mathrm{Y}$ is the excretion of purine derivatives (mmol/day)

$X$ corresponds to the absorbed microbial purines (mmol/day

$\mathrm{BW}^{0.75}$ corresponds to the body weight raised to the 0.75 power (metabolic weight)

The intestinal flow of microbial $\mathrm{N}(\mathrm{g} \mathrm{MN} / \mathrm{d})$ was estimated based on the amount of purines that were absorbed (X mmol/day), according to the equation of Chen \& Gomes (1992): $\mathrm{MN}(\mathrm{g} / \mathrm{d})=\mathrm{X}(\mathrm{mmol} / \mathrm{day}) \times$ $70 / 0.116 \times 0.831000=0.727 X$, assuming a digestibility of 0.83 for microbial purines, a ratio of 0.116 for purine N:total $\mathrm{N}$, and a $\mathrm{N}$ content of purines of $70 \mathrm{mg} \mathrm{N} / \mathrm{mmol}$.

The data were analyzed according to a 5.5 Latin square design, using the PROC GLM and PROC REG procedure of Statistics Analysis System (SAS, 2013) according to the following model:

$Y_{i j k l}=\mu+D_{i}+a_{j}+p_{k}+\varepsilon_{i j k l}$

where: $\mu$ is the general constant

$D_{\mathrm{i}}$ the fixed effect of diet I

$a_{\mathrm{j}}$ is the random effect of animal $\mathrm{j}$

$p_{\mathrm{k}}$ is $\mathrm{t}$ random effect of the experimental period $\mathrm{k}$

$\varepsilon_{\mathrm{ijkl}}$ is the unobservable random error

After analysis of variance, the significance of the linear and quadratic effects of the replacement of the total of wheat bran in the basal diet by spineless cactus was evaluated. A significance value of 0.05 was adopted as the critical value of the probability of type I error to determine the effects of replacing wheat bran with spineless cactus on nutrient intake, feeding behaviour, nitrogen balance, and microbial protein 
synthesis.

\section{Results and Discussion}

The nutrient intake demonstrated a quadratic effect $(P<0.05)($ Table 3$)$. For $\mathrm{DM}$, the maximum intakes of $1414 \mathrm{~g} /$ day and $41.4 \mathrm{~g} / 100 \mathrm{~g}$ body weight were estimated with 80.2 and $80.3 \%$ replacements of wheat bran with spineless cactus plus urea, respectively. The same trends $(P<0.05)$ were observed for intakes of OM (1281 g/day), CP (204 g/day), and total digestible nutrients (890 g/day), estimated with 75.3, 88.6, and $79.3 \%$ replacements of wheat bran, respectively.

Table 3 Intake of nutrients in sheep fed diets containing various replacement levels of wheat bran with spineless cactus

\begin{tabular}{lccccccc}
\hline \multirow{2}{*}{ Item } & \multicolumn{9}{c}{ Replacement levels (\% DM) } & \multirow{2}{*}{ SEM } & \multirow{P}{*}{ value } \\
\cline { 2 - 6 } & $\mathbf{0}$ & $\mathbf{2 5}$ & $\mathbf{5 0}$ & $\mathbf{7 5}$ & $\mathbf{1 0 0}$ & & \\
\hline Intake (g/day) & & & & & & & \\
$\quad$ Dry matter & 949 & 1170 & 1348 & 1426 & 1376 & 99.5 & 0.013 \\
$\quad$ Organic matter & 896 & 1091 & 1243 & 1303 & 1246 & 91.7 & 0.012 \\
$\quad$ Crude protein & 124 & 158 & 190 & 204 & 202 & 14.1 & 0.008 \\
$\quad$ NDFap & 380 & 406 & 429 & 415 & 377 & 33.5 & 0.045 \\
$\quad$ Non-fibre carbohydrates & 363 & 497 & 595 & 658 & 649 & 44.5 & 0.009 \\
$\quad$ Total digestible nutrients & 599 & 715 & 866 & 898 & 861 & 69.9 & 0.007 \\
$\quad$ Intake (g/100 g of body weight) & & & & & & & \\
$\quad$ Dry matter & 27.5 & 34.0 & 39.3 & 41.9 & 39.9 & 2.72 & 0.015 \\
$\quad$ Neutral detergent fibre & 11.0 & 11.8 & 12.5 & 12.2 & 10.9 & 0.95 & 0.043 \\
\hline
\end{tabular}

SEM: standard error of mean

${ }^{1}$ NDFap: neutral detergent fibre corrected for ash and protein

The nutrient intake increase could be explained by the increase in the contents of the NFC of the diets, probably because of the better digestibility of the spineless cactus. There was an increase of nutrient intake up to replacement levels close to $80 \%$. The positive effect on the intake with the inclusion of spineless cactus at levels up to $52 \%$ of DM, despite the increased NFC contents, is justified by the better rumen equilibrium, which is supported by the presence of effective fibre from the sugarcane, helping to maintain microbial activities.

The presence of an excessive amount of urea in the diets, as proven by the increase in plasmatic urea nitrogen, affected not only the palatability of the diet, but also the rumen fermentation. The energy that was released through the fermentation of NFC was probably not enough for the assimilation of a high amount of readily available non-protein nitrogen (NPN) by rumen microorganisms.

According to Mertens (1987), animals consume feed until they achieve the maximum capacity of intake, which is a function of the characteristics of the diet. Thus, another hypothesis regarding the quadratic effect of nutrient intake is the physical limitation of voluntary intake caused by rumen filling owing to the high NDF content of sugarcane (Oliveira et al., 2011), which increased the iNDF content of the diets (Table 2). The low fibre digestibility of the sugarcane reduced the DM intake (Allen, 2000) owing to the greater retention of this fraction in the digestive tract (Voltolini et al., 2008), which affects degradability (Lund et al., 2007). Indigestible material accumulation in the rumen contributes to satiety owing to filling (Magalhães et al., 2006).

The maximum intake $(P<0.05)$ of NDFap $(425 \mathrm{~g} /$ day and $12.8 \mathrm{~g} / 100 \mathrm{~g}$ bodyweight) was estimated with a 50.5 and $60.4 \%$ replacement of wheat bran with spineless cactus plus urea, respectively (Table 3 ). The lower NDFap contents in the diets justify the reduction in the intake of this nutrient in association with a $50 \%$ replacement level, because of the presence of increasing amounts of NFC that are associated with the inclusion of spineless cactus. Despite this reduction, around $31 \%$ of NDFap in the diet promoted the maximum intake of DM by the animals. For lactating cows, NRC (2001) recommends a maximum of $44 \%$ NFC (DM basis) and a minimum of $25 \%$ NDF with a source of effective fibre. Because there are no maximum limits of NFC for sheep, this species might be more tolerant when compared with cattle, something 
that may be related to the feeding habits of the animals.

Feeding behaviour was not altered $(P>0.05)$ by the replacement of wheat bran with spineless cactus plus urea (Table 4). The average times of feeding, rumination, and resting were 322,499 , and $618 \mathrm{~min} /$ day, respectively. Except for the efficiency of the rumination of DM, which increased linearly $(P<0.05)$, the feed efficiency of the DM and the rumination efficiency of the NDF were not affected by the diets, with average values of 247 and $50 \mathrm{~g} / \mathrm{h}$, respectively.

Table 4 Feeding behaviour of sheep fed diets containing various replacement levels of wheat bran with spineless cactus

\begin{tabular}{lccccccc}
\hline \multirow{2}{*}{ Item } & \multicolumn{9}{c}{ Replacement levels (\% DM) } & \multirow{2}{*}{ SEM } & \multirow{2}{*}{$\boldsymbol{P}$ value } \\
\cline { 2 - 5 } & $\mathbf{0}$ & $\mathbf{2 5}$ & $\mathbf{5 0}$ & $\mathbf{7 5}$ & $\mathbf{1 0 0}$ & & \\
\hline Feeding time (min/day) & 308 & 306 & 290 & 316 & 392 & 0.555 & 0.076 \\
Rumination time (min/day) & 546 & 510 & 468 & 518 & 454 & 0.595 & 0.305 \\
Resting time (min/day) & 586 & 624 & 682 & 606 & 594 & 0.728 & 0.359 \\
Feed efficiency (g DM/h) & 190 & 223 & 320 & 280 & 222 & 0.047 & 0.085 \\
Rumination efficiency (g DM/h) & 110 & 140 & 180 & 170 & 190 & 0.019 & 0.001 \\
Rumination efficiency (g NDF/h) & 40 & 50 & 60 & 50 & 50 & 0.007 & 0.385 \\
\end{tabular}

SEM: standard error of mean

According to Welch \& Smith (1971), rumination activity is strongly stimulated by the presence of fibre material in the rumen. It can be inferred that the increase in the rumination efficiency of the DM was owing to the increased inclusion rate of spineless cactus, because masticatory activity is a response to fibre effectiveness (Colenbrande et al., 1991). Thus, when a more fibrous feed is exchanged, as in the replacement of wheat bran (43.4\% of NDFap) by spineless cactus (23.2\% of NDFap), there is a decrease in the masticatory time owing to the lack of the effective NDF of the spineless cactus.

A quadratic effect $(P<0.05)$ was observed for the ingested and absorbed nitrogen values, with maximum amounts estimated at 33.2 and $28.4 \mathrm{~g} /$ day for the replacement levels of 92.7 and $98 \%$ respectively (Table 5). Experimental diets were formulated on an isoprotein basis (Table 2). However, the presence of NPN from urea instead of true protein may explain the higher values in the diets with higher replacement levels. Because of the replacement of the true protein of wheat bran by urea, it can be inferred that there was an increase in rumen degradable protein (RDP), which is probably because of the increase in the ammonia concentration of the rumen (Bach et al., 2005).

Replacement of wheat bran with spineless cactus did not alter $(P>0.05)$ the nitrogen loss from faeces, with an average value of $4.55 \mathrm{~g} /$ day (Table 5), which is probably due to the greater use of rumen $\mathrm{NH}_{3}-\mathrm{N}_{\text {by }}$ bacteria. However, there was a quadratic effect on nitrogen loss from urine representing approximately $19.7 \%$ of the ingested nitrogen in the diets with spineless cactus plus urea. The maximum nitrogen loss from urine $(6.21 \mathrm{~g} / \mathrm{day})$ was estimated with a $70.3 \%$ replacement of wheat bran.

When the rumen degradation rate of protein exceeds the degradation rate of carbohydrates there is an increase of nitrogen excretion and urea production. The excess ammonia that is produced in the rumen is absorbed by the rumen wall and converted to urea in the liver. The excretion of urea in urine represents a higher energy cost for the animal (Nocek \& Russell, 1988). This process uses $12 \mathrm{kcal} / \mathrm{g} \mathrm{N}$ (Van Soest, 1994) or $1 \mathrm{ATP} / \mathrm{molecule}$ of produced urea, resulting in a reduction of the energy that is available for microbial protein synthesis (Bach et al., 2005).

The replacement of wheat bran with spineless cactus plus urea did not alter the concentration of retained nitrogen, which represented $78 \%$ of absorbed nitrogen (Table 5). However, for the retained nitrogen in relation to the ingested nitrogen, there was an increase of $0.07 \%$ for every $1 \%$ increase in the replacement levels due to the fast urea degradation in the rumen environment. 
Table 5 Nitrogen balance of sheep fed diets containing various replacement levels of wheat bran with spineless cactus

\begin{tabular}{|c|c|c|c|c|c|c|c|}
\hline \multirow{2}{*}{ Item } & \multicolumn{5}{|c|}{ Replacement levels (\% DM) } & \multirow{2}{*}{ SEM } & \multirow{2}{*}{$P$ value } \\
\hline & 0 & 25 & 50 & 75 & 100 & & \\
\hline $\mathrm{N}$ ingested (g/day) & 19.8 & 25.3 & 30.3 & 32.7 & 32.3 & 2.26 & 0.009 \\
\hline $\mathrm{N}$ absorbed (g/day) & 15.5 & 20.3 & 25.6 & 27.9 & 28.2 & 1.84 & 0.006 \\
\hline $\mathrm{N}$ faecal (g/day) & 4.30 & 4.99 & 4.74 & 4.72 & 4.01 & 0.54 & 0.375 \\
\hline $\mathrm{N}$ urinary (g/day) & 3.23 & 5.20 & 5.68 & 6.84 & 6.06 & 0.95 & 0.002 \\
\hline $\mathrm{N}$ retained (\%N absorbed) & 80.9 & 72.3 & 78.0 & 75.9 & 78.8 & 0.01 & 0.287 \\
\hline $\mathrm{N}$ retained (\%N ingested) & 63.6 & 58.0 & 66.3 & 65.1 & 69.0 & 0.04 & $<0.001$ \\
\hline $\mathrm{N}$ retention (g/day) & 12.2 & 15.1 & 19.9 & 21.1 & 22.2 & 1.58 & $<0.001$ \\
\hline $\mathrm{N}$ retention $\left(\mathrm{g} / \mathrm{kg} \mathrm{BW}^{0.75}\right)$ & 0.96 & 1.20 & 1.58 & 1.67 & 1.76 & 0.13 & $<0.001$ \\
\hline $\mathrm{PUN}^{1}(\mathrm{mg} / \mathrm{dL})$ & 76.3 & 75.3 & 78.5 & 98.3 & 90.1 & 6.91 & 0.005 \\
\hline
\end{tabular}

SEM: standard error of the mean. 'PUN: plasma urea nitrogen.

There was an increase of $0.10 \mathrm{~g} /$ day in the nitrogen retention for every $1 \%$ replacement of wheat bran with spineless cactus plus urea (Table 5). Independent of the replacement levels, there was no negative nitrogen retention, indicating that protein intake was adequate for the protein requirements of the sheep. A higher nitrogen retention was observed with the total replacement of wheat bran for the diet containing $49.2 \%$ of spineless cactus and $3.94 \%$ urea.

The plasmatic concentration of PUN increased by $0.20 \mathrm{mg} / \mathrm{dL}$ for every $1 \%$ replacement of wheat bran with spineless cactus plus urea (Table 5). The average values observed for PUN (75.3-98.3 mg/dL) were above the physiologic levels considered normal (24-60 mg/dL) by González \& Silva (2006). According to Butler (1998), the plasmatic concentration of urea nitrogen in ruminants is related to protein intake, and is used to verify the nutritional protein status of animals. In this study, there was probably an imbalance between RDP/RUP and the energy of the diet owing to excess urea (González et al., 2000), promoting a greater accumulation of ammonia in the rumen.

The replacement of nitrogen from wheat bran by NPN from urea, a product more soluble in the rumen, contributed to increasing PUN in the sheep (Table 5). Despite the gradual increase in PUN, intoxication was not recorded in the animals that received up to $39.4 \mathrm{~g}$ urea $/ \mathrm{kg}$. However, above $31.6 \mathrm{~g} / \mathrm{kg}$ of supplied urea, there was a reduction in DM intake (with $80 \%$ replacement).

The excretion of purine derivatives presented a quadratic effect $(P<0.05)$ (Table 6), except for uric acid, which increased linearly by $0.10 \mathrm{mmol} /$ day for every $1 \%$ level of replacement. The maximum excretions of allantoin (18.3 mmol/day) and xanthine + hypoxanthine $(1.88 \mathrm{mmol} /$ day $)$ were estimated with $43.8 \%$ and $45.7 \%$ replacements of wheat bran, respectively. The maximum excretion of the total $(21.3 \mathrm{mmol} / \mathrm{day})$ and absorbed purines (25.3 mmol/day) were estimated for the replacement levels of $45.6 \%$ and $45.64 \%$ respectively. Maximum microbial nitrogen production of $15.9 \mathrm{~g} /$ day and microbial protein synthesis of 99.4 g/day were estimated for 45.8 and $45.7 \%$ replacements of wheat bran.

When crude protein intake increases, there is an increase in the urinary excretion of purine derivatives, indicating a greater duodenal flow of microbial proteins (Balcells et al., 1991).

At above $46 \%$ replacement of wheat bran, there was a reduction in microbial protein synthesis. This result could be explained by the greater amount of urea that was added to the diets (Table 2). Besides limiting the DM intake of the diets (Table 3) owing to fast rumen degradation, this caused an imbalance in the energy/nitrogen ratio (Table 5) that was available for the microorganisms. Therefore, the microorganisms could not use the total amount of ammonia that was available in the rumen, increasing nitrogen loss and decreasing microbial protein synthesis, and consequently decreasing the $\mathrm{N}$ flow to the duodenum.

The smaller microbial protein production with the replacement of $100 \%$ of wheat bran could be explained by the presence of low ruminal digestibility of fibre of sugarcane, resulting in lower energy available for rumen bacterias. This was observed by Pires et al. (2008), who reported a lower microbial CP flow in diets containing 100\% sugarcane, indicating less efficient fermentation. According to these authors, a lower passage rate of sugarcane could contribute to lower microbial CP production. According to Russell et al. (1992), a lower rumen turnover indicates that the energy demand is greater, resulting in slower microorganism growth. 
Table 6 Urinary purine derivatives and microbial protein synthesis of sheep fed diets containing various replacement levels of wheat bran with spineless cactus

\begin{tabular}{|c|c|c|c|c|c|c|c|}
\hline \multirow{2}{*}{ Item } & \multicolumn{5}{|c|}{ Replacement levels (\% DM) } & \multirow{2}{*}{ SEM } & \multirow{2}{*}{$P$ value } \\
\hline & 0 & 25 & 50 & 75 & 100 & & \\
\hline \multicolumn{8}{|l|}{ Purine derivatives ( $\mathrm{mmol} / \mathrm{day})$} \\
\hline Allantoin & 12.5 & 18.8 & 16.3 & 16.7 & 9.06 & 1.47 & $<0.001$ \\
\hline Uric acid & 0.45 & 0.99 & 1.10 & 1.35 & 1.53 & 0.09 & $<0.001$ \\
\hline Xanthine + hypoxanthine & 1.56 & 1.65 & 1.86 & 1.88 & 1.24 & 0.11 & 0.001 \\
\hline Total purine derivatives & 14.5 & 21.4 & 19.3 & 19.9 & 11.8 & 1.54 & 0.001 \\
\hline Microbial purines absorbed (mmol/day) & 19.4 & 25.3 & 23.5 & 24.0 & 17.1 & 1.41 & 0.001 \\
\hline Microbial N supply (g/day) & 12.2 & 15.8 & 14.8 & 15.1 & 10.8 & 0.89 & 0.001 \\
\hline Microbial protein (g/day) & 76.3 & 98.7 & 92.5 & 94.5 & 67.5 & 5.57 & 0.001 \\
\hline $\operatorname{EMNS}^{1}\left(\mathrm{~g} / 100 \mathrm{~g} \mathrm{TDN}^{2}\right)$ & 117 & 130 & 98.7 & 97.1 & 70.8 & 8.91 & $<0.001$ \\
\hline
\end{tabular}

SEM: standard error of mean

${ }^{1}$ EMNS: efficiency of microbial protein supply

${ }^{2}$ TDN: total digestible nutrients

The efficiency of microbial protein synthesis was reduced linearly by approximately $0.50 \mathrm{~g}$ for each $100 \mathrm{~g}$ TDN (Table 6). According to NRC (2001), an increase in the microbial protein synthesis depends on the availability of carbohydrates and nitrogen in the rumen. However, the efficiency of microbial growth, according to Nocek \& Russell (1988), depends on the energy partition for maintenance and growth. Thus, microbial growth is maximized by synchronization between the availability of fermentable energy and rumen degradable nitrogen (Russell et al., 1992). Therefore, in this study, it is possible that the fibre content of sugarcane in particular increased the iNDF in the diets (Table 2). This may have limited TDN intake, causing lower microbial efficiency.

Del Razo et al. (2015) and Einkamerer et al. (2009) suggested that spineless cactus could replace the roughage proportion in diets. Nevertheless, the present study showed that spineless cactus could replace a significant part of concentrate feedstuff as wheat bran. This becomes crucial for semi-arid regions once this input cannot be produced, necessitating its importation from other areas and consequent high prices. The total cost per kilo DM according to current prices was estimated at (U\$/kg DM) $0.29 ; 0.23 ; 0.21 ; 0.19$, and 0.18 for replacement of $0 \%, 25 \%, 50 \%, 75 \%$, and $100 \%$, respectively.

\section{Conclusions}

Spineless cactus plus urea is a useful alternative feed option in semi-arid regions during the shortage of feed and water in prolonged drought. This study proved that spineless cactus could replace up to $80 \%$ of wheat bran in sugarcane-based diets for sheep, promoting a higher intake of DM and TDN, and consequently could reduce dependence on feed concentrates and the feeding costs.

\section{Authors' Contributions}

SEBL was responsible for execution of experiment, laboratorial analysis, paper edition and final corrections. RAP, JMSC, JLS and JCCC contributed to paper edition and final corrections. MAF was responsible for supervision of project, experiment conception, supervision of project, statistical analysis and paper edition. JABAS, SAS and TTBM contributed to execution of experiment and laboratorial analysis.

\section{Conflict of Interest Declaration}

The authors wish to confirm that there are no known conflicts of interest associated with this publication and there has been no significant financial support for this work.

\section{References}

Allen, M.S., 2000. Effects of diet on short-term regulation of feed intake by lactating dairy cattle. J. Anim. Sci. 83, 15981624.

AOAC, 1990. Official methods of analysis (15th ed.). Association of Official Analytical Chemists, Inc., Arlington, Virginia, 
USA.

Bach, A., Calsamiglia, S. \& Stern, M.D., 2005. Nitrogen metabolism in the rumen. J. Dairy Sci. 88, 9-21.

Balcells, J., Guada, J.A., Castrillo, C. \& Gasa, J., 1991. Urinary excretion of allantoin and allantoin precursors by sheep after different rates of purine infusion into the duodenum. J. Agric. Sci. 116, 309-317.

Bastos, M.P.V., Carvalho, G.G.P., Pires, A.J.V., Silva, R.R., Eustáquio, Filho A., Santos, E.J., Chagas, D.M.T., Barroso, D.S. \& Abreu Filho, G., 2014. Ingestive behaviour and nitrogen balance of confined Santa Ines lambs fed diets containing soyabean hulls. Asian-Austr. J. Anim. Sci. 27, 24-29.

Ben Salem, H. \& Smith, T., 2008. Feeding strategies to increase small ruminant production in dry environments. Small Rumin. Res. 77, 174-194.

Bürger, P.J., Pereira, J.C., Queiroz, A.C.D., Silva, J.F.C., Valadares Filho, S.C., Cecon, P.R. \& Casali, A.D.P., 2000. Ingestive behavior in Holstein calves fed diets with different concentrate levels. Rev. Bras. Zootec. 29, $236-242$.

Butler, W.R., 1998. Symposium: Optimizing protein nutrition for reproduction and lactation. J. Dairy Sci. 81, 2533-2539.

Del Razo, O.E., Almaraz, I., Espinosa, V., Soriano, R., Miranda, L.A., Arias, L., Guan, L., Buendía, G. \& Pelaez, A. 2015. Comparative analysis of the in vitro fermentation of wasted cladodes (Opuntia spp.), lucerne and oat hays. S. Afr. J. Anim. Sci. 45, 470-475.

Einkamerer, O.B., Waal, H.O. de, Combrinck, W.J. \& Fair, M.D. 2009. Feed utilization and growth of Dorper wethers on Opuntia-based diets. S. Afr. J. Anim. Sci. 39, 53-57.

Chen, X.B. \& Gomes, M.J., 1992. Estimation of microbial protein supply to sheep and cattle based on urinary excretion of purine derivatives - an overview of technical details. In: International Feed Research Unit. Rowett Research Institute, Aberdeen. pp. 21.

Colenbrande, V.F., Noller, C.H. \& Grant, R.J., 1991. Effect of fiber content and particle size of alfalfa silage on performance and chewing behavior. J. Dairy Sci. 74, 2681-2681.

Ferreira, M.A., Pessoa, R.A.S., Silva, F.M. \& Bispo, S.V., 2011. Palma forrageira e ureia na alimentação de vacas leiteiras. EDUFRPE, Recife, Brasil. 40 pp. (in Portuguese).

González, F.H.D., Barcellos, J.O., Ospina, H. \& Ribeiro, L.A.O., 2000. Perfil Metabólico em ruminantes: seu uso em nutrição e doenças nutricionais. Gráfica da Universidade Federal do Rio Grande do Sul, Porto Alegre, Brasil. 108 pp. (in Portuguese).

González, F.H.D. \& Silva, S.C., 2006. Introdução à Bioquímica Clínica Veterinária. 2nd ed. UFRGS: Porto Alegre, Brasil. 364pp. (in Portuguese).

Hall, M.B., 2000. Calculation of non-structural carbohydrate content of feeds that contain non-protein nitrogen. Bull., University of Florida, Florida. No. 339, pp. A-25.

Licitra, G., Hernandez, T.M. \& Van Soest, P.J., 1996. Standardization of procedures for nitrogen fractionation of ruminant feeds. Anim. Feed Sci. Technol. 57, 347-358.

Lund, P., Weisbjerg, M.R. \& Hvelplund, T., 2007. Digestible NDF is selectively retained in the rumen of dairy compared to indigestible NDF. Anim. Feed Sci. Technol. 134, 1-17.

Magalhães, A.L.R., Campos, J.M.S., Cabral, L.S., Mello, R., Freitas, J.A., Torres, R.A., Valadares Filho, S.C. \& Assis, A.J., 2006. Effects of replacing corn silage with sugarcane on production and ruminal metabolism of lactating dairy cows. Rev. Bras. Zootec. 35, 591-599. (in Portuguese, English abstract).

Menezes, G.C.C., Valadares Filho, S.C., Magalhães, F.A., Valadares, R.F.D., Mariz, L.D., Detmann, E., Pereira, O.G. \& Leão, M.I., 2011. Total and partial digestibility, rates of ingestion obtained with rumen evacuation and microbial protein synthesis in bovines fed fresh or ensiled sugar cane and corn silage. Rev. Bras. Zootec. 40, 1105-1113.

Mertens, D.R., 1987. Predicting intake and digestibility using mathematical models of ruminal function. J. Dairy Sci. 64, 1548-1558.

Mertens, D.R., 2002. Gravimetric determination of amylase-treated neutral detergent fiber in feeds with refluxing in beakers or crucibles: collaborative study. J. AOAC Int. 85, 1217-1240.

Monteiro, C.C.F., Melo, A.A.S., Ferreira, M.A., Campos, J.M.S., Souza, J.S.R., Silva, E.T.S., Andrade, R.P.X. \& Silva, E.C., 2014. Replacement of wheat bran with spineless cactus (Opuntia ficus indica Mill cv Gigante) and urea in the diets of Holstein x Gyr heifers. Trop. Anim. Health Prod. 46, 1149-1154.

NRC, 2001. Nutrient requirements of dairy cattle (7th ed.). National Academy Press, Washington D.C., USA.

Nefzaoui, A. \& Ben Salem, H., 2002. Forage, fodder, and animal nutrition. In: Cacti: Biology and Uses. Ed: Nobel, P.S. \& Park, S., University of California Press, Berkeley and Los Angeles, CA. pp. 199-210.

Nobel, P.S., 2001. Ecophysiology of Opuntia ficus indica. In: Cactus (Opuntia spp.) as forage. Edited by C. MondragónJacobo \& S. Pérez-González, S. Food and Agriculture Organization of the United Nations, Rome.

Nocek, J.E. \& Russell, J.B. 1988. Protein and energy as an integrated system. Relationship of ruminal protein and carbohydrate availability to microbial synthesis and milk production. J. Dairy Sci. 71, 2070-2107.

Oliveira, A.S., Detmann, E., Campos, J.M.S., Pina, D.S., Souza, S.M. \& Costa, M.G., 2011. Meta-analysis of the impact of neutral detergent fiber on intake, digestibility and performance of lactating dairy cows. Rev. Bras. Zootec. 40, 1587-1595. (in Portuguese, English abstract)

Pires, A.V., Susin, I.M., Santos, F.A.P., Mendes, C.Q., Oliveira, R.C., Fernandes, J.J.R. \& Simas, J.M.C., 2008. Effect of starch sources and processing on performance and nitrogen metabolism in lactating Holstein cows. Rev. Bras. Zootec. 37, 1456-1462. (in Portuguese, English abstract)

Russell, J.B., O'Connor, J.D., Fox, D.G., Van Soest, P.J. \& Sniffen, C.J., 1992. A net carbohydrate and protein system for evaluating cattle diets I. Ruminal fermentation. J. Anim. Sci. 70, 3551.

SAS, 2013. Statistical Analysls System user's guide (Version 9.4). SAS Institute Inc., Cary, North Carolina, USA.

Storry, J.E. \& Sutton, J.D., 1969. The effect of change from low-roughage to high-roughage diets on rumin fermentation, blood composition and milk fat secretion in the cow. Brit. J. Nutr. 23, 511-521. 
Van Soest, P.J., 1994. Nutritional ecology of the ruminant. 2nd ed. Comstock, Ithaca. 476 pp.

Voltolini, T.V., Santos, F.A.P., Martinez, J.C., Bittar, C.M.M., Imaizumi, H. \& Cortinhas, C.S., 2008. Different metabolizable protein levels in sugar cane diets to lactating dairy cows. Ci. Anim. Bras. 9, 309-318. (in Portuguese, English abstract)

Wangsness, P.J., Chase, L.E., Peterson, A.D., Hartsock, T.G., Kellmel, D.J. \& Baumgardt, B.R., 1976. System for monitoring feeding behavior of sheep. J. Anim. Sci. 42, 1544-1549.

Weiss, W.P., 1999. Energy prediction equations for ruminant feeds. Proc. 61st Cornell Nutrition Conference for Feed Manufacturers, Cornell University, Ithaca. pp.176-185.

Welch, J.G. \& Smith, A.M., 1971. Effects of beet pulp and citrus pulp on rumination activity. J. Anim. Sci. 33, $472-475$. 